\title{
The Effect of Job Satisfaction and Workload on IT Project Employee Turnover Intention in the Madinah Government of Saudi Arabia
}

\author{
Umar A. Altahtooh \\ Taibah University \\ Madinah, Saudi Arabia
}

\begin{abstract}
The employee turnover ratio in information technology (IT) projects has become a main concern that needs to be resolved. This paper discovers the impact of job satisfaction and workload on the turnover intention of employees in IT projects in the Madinah Government of Saudi Arabia. The relationships between job satisfaction and workload on turnover intention are examined. A survey questionnaire was used to gather data from 56 IT employees for this study. The findings indicate that employees experienced a moderate level of job satisfaction and workload. Workload was significantly and positively related to turnover intention. The results indicate that a significant negative relationship exists between job satisfaction and turnover intention.
\end{abstract}

Keywords: Employee Turnover, IT Project, Madinah, Saudi Arabia

\section{Introduction}

Employee turnover has been a national crisis for decades and is still a hot topic for researchers and practitioners in different industries. According to Nelson and Todd (2004), the rate of information technology (IT) employee turnover is around $15 \%$ in many firms. Within the first year, $25 \%$ of highly potential staff tend to leave firms (Martin and Schmidt, 2010). According to Lo (2013), substituting an IT manager can cost up to $200 \%$ of an employee's salary in an organization. Furthermore, IT employee turnover costs firms about $150 \%$ of an employee's annual income (Hester, 2013). A high employee turnover rate can be costly and time consuming for the IT industry. IT career paths can be classified into two categories: IT technical careers and IT managerial careers. When IT employees leave, organizations bear two types of costs: hiring costs and vacancy costs. The expected cost of IT employee turnover in organizations is approximately $\$ 44$ billion each year (Essex, 2000). According to the State of Kansas (1998), IT projects include any implementation of computers, telecommunications, and IT improvement with costs higher than $\$ 250,000$. The U.S. needs more than 1.3 million new and highly skilled IT employees to address the shortage of IT professionals (Kamal, 2005). The number of IT jobs is expected to increase by 25\%, while all other job categories are expected to increase by only $10 \%$ based on the U.S. Bureau of Labor Statistics (Dohm and Shniper, 2007). The U.S. spends around\$250 billion every year on IT projects (Standish Group, 1994). Saudi Arabia has the largest IT market in the Middle East, of which the value was SAR111.98 billion in 2014 (CITC, 2015).

In project management, human resources is one of the main knowledge areas of the Project Management Body of Knowledge (PMBOK ${ }^{\circledR}$ Guide). Saudi government organizations have human resource policies that seek to be less a burden in accordance with the Saudi Vision 2030 (2016). According to Mello (2014), investment is gone when an employee leaves, even though an organization has massively invested in training and development. One of the most significant sides of effective human resources within project management is related to employee turnover. BenBaker et al. (1994, p.449) state that "Turnover is an important organizational outcome with costly and disruptive effects." To reduce IT project employee turnover, the impact of turnover should be explored. Recently, many efforts have been made to deal with turnover to understand the causes behind it. However, this study focuses on job satisfaction and workload that affects IT project employee turnover intention.

Thus, this paper is empirical in nature, based on the survey method because it is the first effort in discovering the level of job satisfaction, workload and turnover intention among IT project employees in the Madinah Government of Saudi Arabia. Understanding the factors affecting IT turnover intention may help to generate new strategies for the workforce in IT departments within the Madinah Government. 
This study aims to provide a relational perspective on turnover by addressing this question: What are the relationships between job satisfaction and workload on turnover intention in IT projects in the Madinah Government?

To answer the above question, the study employs a questionnaire methodology, targeting IT project employees, to investigate the relationships of factors affecting turnover intention using quantitative software (SPSS). The paper is organized as follows: Section 2 discusses the literature review regarding employee turnover. Section 3 describes the research model and methodology. Section 4 presents findings of the questionnaire regarding turnover intention. Finally, the study sums up the conclusions of the findings and provides recommendations for additional research in Section 5 .

\section{Literature Review}

\subsection{Employee Turnover}

Employee turnover leads to a huge waste of money in different organizations. According to Reeves (2012), depending on the company and position, the cost of turnover can reach between $\$ 2,300$ and $\$ 13,000$ per employee. Most organizations invest a huge amount of resources, such as time, money, training, and development on new employees, thus, turnover is critical (Kazi and Zadeh, 2011). This part aims to discover the concept of employee turnover. Turnover is defined as "a common consequence of poor experiences in the initial stages of integration in a new organization" (Perez et al., 2013, p.51). Tette and Meyer (1993, p.262) define turnover as "a conscious and deliberate willfulness to leave the organization."

Plenty of studies with multiple perspectives have been conducted by scholars on employee turnover. According to Griffeth and Hom (1995), turnover happens when an employee considers leaving an organization through personal choice. Simply, turnover is "the reverse position of an employee in organization" (Khan, 2014, p.26). Employee turnover happens when a new employee is hired and educated against a vacancy as part of a replacement cycle (Woods, 1995). Turnover is associated with various direct and indirect costs. Bliss (2004) shows that recruitment costs, new hire costs, training costs, lost productivity costs, and lost sales costs are associated with employee turnover. There are two types of employee turnover (Armstrong, 2006). Voluntary turnover happens when an employee chooses to seek alternative employment. Involuntary turnover can be happened due to some special factors such as ill health or death, retirement, or an organization's decision to discharge an employee. According to empirical studies, voluntary turnover is costly for firms as it reduces productivity and quality (Holtom and Burch, 2016). Also, it negatively affects the competitive advantage for organizations (Sanjeevkumar, 2012).

Studies suggest numerous factors affecting IT employee turnover in organizations by examining turnover intention as the dependent variable. It is evident from the IT turnover literature review that many scholars focus on job satisfaction and organizational commitment as the most widely studied variables. Most empirical studies have shown a negative relationship between job satisfaction and turnover (e.g. Igbaria and Siegel, 1992; Jiang and Klein, 2002; Kim and Wright, 2007). Low job satisfaction is a critical factor that leads to turnover intention. When employees have a low level of job satisfaction, they are more likely to leave their employers (Hammerberg, 2002). Meyer and Allen (1997) suggest that there is a negative relationship between organizational commitment and turnover intention. However, job satisfaction has a more direct effect on turnover intention than organizational commitment (Igbaria and Siegel, 1992).

Furthermore, factors of autonomy, job feedback, task significance, skill variety, and task identity (Job Characteristics Model-JCM) have a negative impact on turnover intention (Hackman and Oldham, 1980). According to Igbaria and Siegel (1992), low pay leads to turnover intention. In terms of role context, increasing role clarity helps to decrease IT employee turnover in the private sector (Baroudi, 1985).

\subsection{Job Satisfaction}

A job is a group of tasks executed by an employee in a specific physical and social environment linked to financial compensation. Satisfaction is a function of the inconsistency between wishes and effects. Spector (1997) defines job satisfaction as the feelings that employees have about their job. Job satisfaction can be attributed to "an emotional, cognitive, behavioral component" (Bernstein and Nash, 2008). Job satisfaction is related to positive emotions of employees towards a place of work. Locke (1969) defines job satisfaction as "the pleasurable emotional state resulting from the appraisal of one's job as achieving or facilitating the achievement of one's job values" (p.316). Job satisfaction is defined as "an attitude toward one's job" (Brief, 1998). 
Moreover, satisfaction with pay, promotion, supervision, and the workplace leads to overall job satisfaction. An employee's self-evaluation is associated with job satisfaction (Judge and Bono, 2001). In terms of environmental context, there is a relationship between satisfaction and the working environment, including job challenge, variety, and scope (Weiner, 2000). Job satisfaction is necessary to increase work production in any firm. The correlation between job and life satisfaction is interrelated. It means that job satisfaction affects life satisfaction, and life satisfaction also affects job satisfaction (Judge and Watanabe, 1994). According to Loher et al. (1985), job enrichment is a way to increase both employee performance and job satisfaction by improving the recognition of employees. In recent studies, several factors are proposed to affect an employee's level of job satisfaction: work environment (Kim, 2005); employee's personality (Judge and Larsen, 2001); and life satisfaction (Jones, 2006). Herzberg et al. (1959) suggest a motivation theory for job satisfaction and this theory can be divided into two categories: motivation factors and hygiene factors. The lack of hygiene factors, such as job security and pay, lead to job dissatisfaction. These factors can only lead to external happiness but are not enough strong to convert job dissatisfaction into job satisfaction. In terms of leadership context, leadership style practices have an important relationship with job satisfaction (Shoemaker, 1999). Thompson (2008) suggests there are positive relationships between job satisfaction, trust, and project success. Job satisfaction is studied as both an independent and a dependent variable. As an independent variable, job satisfaction is related to a range of workplace attitudes, such as turnover intentions.

\subsection{Workload}

It is necessary to first define terminology to realize the nature of workload. Bruggen (2015) defines workload as "being very busy without a direct reference to a specific target" (p.3). According to Laschinger et al. (2001), workload can be defined as work demand. It can be categorized into physical and perceptual workloads (Fox et al., 1993). In terms of mental context, workload is "the difference between the capacities of the information-processing system that are required for task performance, to satisfy expectations and the capacity available at any given time" (Gopher and Donchin, 1986, pp.41-43). Matthews et al. (2000) define workload as "people's experiences of cognitive task performance as effortful and fatiguing" (p.87). According to bowling and Kirkendall (2012), workload includes any variable that reflects the total effort of an employee's work.

There are some relationships between workload and some variables of the work environment. In the context of stressors, workload has been found to cause work exhaustion (Moore, 2000). According to Gaillard (2001), there is relationship between workload and stress. High workload levels lead to stress. Glaser et al. (1999) state that there is a significant relationship between workload and stress, and stress and turnover. The number and difficulty of tasks may cause workload that leads to job stress (Shaw and Weekley, 1985). Furthermore, workload levels have a strong correlation with role conflict (Ortqvist and Wincent, 2006). According to Bowling and Kirkendall (2012), there is a positive relationship between workload and withdrawal. High workload leads to high withdrawal.

\section{Research Model and Hypotheses}

A research model has been developed for this study and hypotheses are formulated based on the literature review. It consists of charts and words to achieve the purpose of study (Mayer, 1989). The research model has been developed to study the influence of job satisfaction and workload on IT project employee turnover intention through the collection and analysis of data.

This study demonstrates the relationship between job satisfaction and workload on turnover intention. Figure 1 shows the research model for this paper.

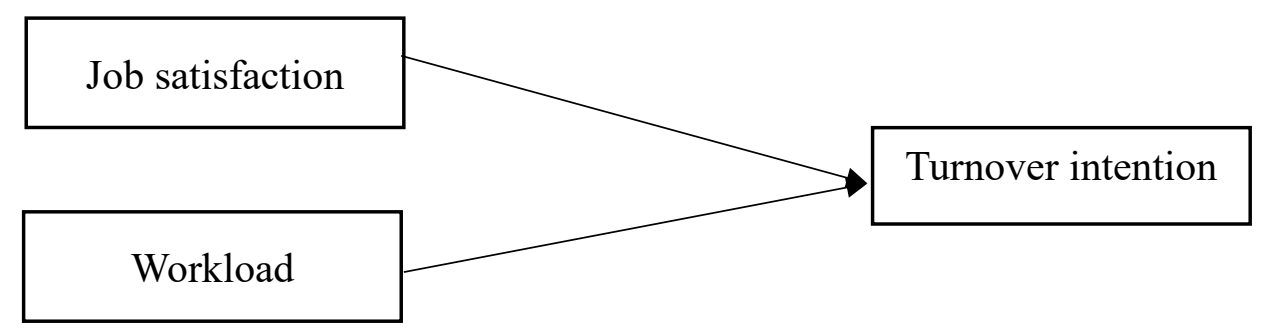

Figure 1: Research Model 
The model includes the following variables:

- Job satisfaction (independent variable).

- Workload (independent variable).

- Turnover intention (Dependent variable).

The results of this study may support researchers and practitioners to help them understand the factors that affect employee turnover in the Madinah Government. Thus, the research model helps to formulate two hypotheses:

H1: Job satisfaction has a direct influence on IT turnover intention.

$\mathrm{H} 2$ : Workload has a direct influence on IT turnover intention.

\section{Methodology}

Survey data were collected from 56 IT project employees. A self-administered questionnaire was developed based on the research model, hypotheses, and an extensive review of literature related to employee turnover. This survey questionnaire was designed to measure the relative influence of job satisfaction and workload on turnover. A stratified quota random sampling technique was adopted to cover the IT project employees across various departments in the Madinah Government. The questionnaire consisted of questions on IT employees' demographic details, job satisfaction, workload, and turnover intention. The sample frame was intended to include only IT employees working in governmental organizations within the public sector in the Madinah Government. A total of 56 completed questionnaire surveys were collected out of the 150 questionnaires distributed, with a response rate of $37.3 \%$. The size of the sample was small because the study focused on one region of Saudi Arabia. The 56 questionnaires were coded and analyzed, adopting the Statistical Package for Social Sciences (SPSS) software.

All items in the survey questionnaire used a five-point Likert scale $(1=$ strongly disagree, $5=$ strongly agree). The data collected through the questionnaires were analyzed using descriptive statistics, mean scores, and standard deviations, and Pearson's correlation coefficient. The purpose of Pearson's correlation coefficient (r) is to measure the strength of the relationship between two variables.

\section{Data Analysis and Results}

\subsection{Reliability Analysis and Descriptive Statistics}

Cronbach's alpha is considered reliable if it is more than 0.70 (DeVellis, 2003). The reliability of the measurement instrument using Cronbach's alpha was $0.76,0.81$, and 0.79 for the three instruments, respectively (see Table 1).

Table 1: Validity and Reliability of Measurement Instrument

\begin{tabular}{ccc}
\hline Instruments & Item & $\begin{array}{c}\text { Cronbach's } \\
\text { alpha }\end{array}$ \\
\hline Job Satisfaction & 5 & 0.76 \\
Workload & 5 & 0.81 \\
Turnover Intention & 6 & 0.79 \\
\hline
\end{tabular}

The descriptive statistics for the demographic profile of respondents are shown in Table 2. This table presents the frequency and percentage distribution of IT employees according to each demographic category. As shown, the majority of the respondents were male $(85.7 \%)$, while $14.3 \%$ were female. The gender gap is still observed in IT projects. In terms of age, the majority of the respondents $(41.1 \%)$ were 30 years old or below, whereas $28.6 \%$ were between 31 and 40 years old, 21.4\% were between 41 and 50 years old, and $8.9 \%$ were aged 51 years and above.

Most of the respondents had qualifications at bachelor level (51.8\%), while $17.9 \%$ had qualifications below bachelor level, $16 \%$ had qualifications at a higher diploma level, $10.7 \%$ had qualifications at master level, and only $3.6 \%$ had qualifications at $\mathrm{PhD}$ level. Regarding their years of experience, most respondents had work experience of 10 years and below (66.1\%), 23.2\% had work experience between 11 and 20 years, and 10.7\% had work experience of 21 years and above. 
Table 2: Demographic Profile of IT Employees

\begin{tabular}{cccc}
\hline & & Frequency & Percentage \\
\hline Gender & Male & 48 & 85.7 \\
& Female & 8 & 14.3 \\
& Total & 56 & 100 \\
Age & & & \\
& 30 and Below & 23 & 41.1 \\
& $31-40$ & 16 & 28.6 \\
& $41-50$ & 12 & 21.4 \\
& 51 and Above & 5 & 8.9 \\
Level of Education & Total & 56 & 100 \\
& & & \\
& Below Bachelor & 10 & 17.9 \\
& Bachelor & 29 & 51.8 \\
& Higher Diploma & 9 & 16 \\
& Master & 6 & 10.7 \\
& PhD & 2 & 3.6 \\
& Total & 56 & 100 \\
& & & \\
Years of Experience & 10 and Below & 37 & 66.1 \\
& $11-20$ & 13 & 23.2 \\
& 21 and Above & 6 & 10.7 \\
& Total & 56 & 100 \\
\hline
\end{tabular}

\subsection{Mean Levels of Variables}

Table 3 shows the mean scores and standard deviations of IT employees' perceptions regarding the independent variables and dependent variable. The mean scores of their responses were interpreted according to a five-point Likert scale to complete the survey questionnaire, and the range of the means wereas follows: $4.21-5.00=$ strongly agree; $3.41-4.20=$ agree; $2.61-3.40=$ moderate agreement; $1.81-2.60=$ disagree; $1.00-1.80=$ strongly disagree.

Table 3: Mean, Standard Deviations of Variables

\begin{tabular}{ccc}
\hline Variables & Mean & SD \\
\hline Job Satisfaction & 3.14 & 0.64 \\
Workload & 3.27 & 0.55 \\
Turnover Intention & 3.38 & 0.59 \\
\hline
\end{tabular}

Overall, IT employees moderately agreed with job satisfaction (mean $=3.14, \mathrm{SD}=0.64)$, workload $(\operatorname{mean}=3.27$, $\mathrm{SD}=0.55)$, and turnover intention (mean $=3.38, \mathrm{SD}=0.59)$ as shown in Table 3 .

\subsection{Test of Hypotheses}

According to Rumsey (2011), Pearson's correlation coefficient (r) ranges between -1 (a perfect negative correlation) and 1 (a perfect positive correlation), with 0 (no correlation). To define the strength of the correlation, the following were used: $\pm 0.10-0.29=$ weak correlation, $\pm 0.30-0.49=$ small correlation, $\pm 0.50-0.69=$ moderate correlation, \pm 0.70 or $>=$ strong correlation.

Pearson's correlation coefficient was used to test the two hypotheses related to the research question:

What are the relationships between job satisfaction and workload on turnover intention in IT projects within the Madinah Government? The relationship between job satisfaction and turnover intention were tested using Pearson's correlation analysis. Table 4 shows the results of the inter-correlation between job satisfaction and turnover intention that are statistically significant at $(\mathrm{p}<.05)$ and $95 \%$ confidence level.

In detail, job satisfaction was found to be moderately correlated and negatively related to turnover intention. 
Pearson's correlation analysis indicated that $r=-0.532, \mathrm{P}=0.000$ significant at 0.01 level (2-tailed). It is suggested that higher job satisfaction leads to a lower turnover intention.

Table 4: Relationship between Job Satisfaction and Turnover Intention

\begin{tabular}{c|l|l}
\hline & Job Satisfaction & Turnover Intention \\
\hline Job Satisfaction Pearson's Correlation & 1 & $-0.532^{* *}$ \\
Sig. (2-tailed) & - & .000 \\
$\mathrm{~N}$ & 56 & 56 \\
\hline $\begin{array}{c}\text { Turnover Intention Pearson's Correlation } \\
\text { Sig. (2-tailed) }\end{array}$ & $-0.532^{* *}$ & 1 \\
$\mathrm{~N}$ & .000 & - \\
\hline
\end{tabular}

**. Correlation is significant at the 0.01 level (2-tailed).

Pearson's correlation analysis was used to test the relationship between workload and turnover intention. Table 5 displays the outcomes of inter-correlation between workload and turnover intention that are statistically significant at $(\mathrm{p}<.05)$ and a $95 \%$ confidence level.

In detail, workload was found to be minimally correlated and positively related to turnover intention. Pearson's correlation analysis indicated that $\mathrm{r}=0.318, \mathrm{P}=0.000$ significant at 0.01 level (2-tailed). It is suggested that higher workload will lead to higher turnover intention.

Table 5: Relationship between Workload and Turnover Intention

\begin{tabular}{rr|l|l}
\hline & & Workload & Turnover Intention \\
\hline Workload & Pearson's Correlation & 1 & $0.318^{* *}$ \\
& Sig. (2-tailed) &. & 000 \\
$\mathrm{~N}$ & 56 & 56 \\
\hline Turnover Intention & Pearson's Correlation & $\begin{array}{l}0.318^{* *} \\
\mathrm{~N}\end{array}$ & $\begin{array}{l}56 \\
56\end{array}$ \\
& Sig. (2-tailed) & 000 & 1 \\
& & 56 \\
\hline
\end{tabular}

**. Correlation is significant at the 0.01 level (2-tailed).

\section{Discussion}

Two main contributions were carried out via this study. Firstly, this is the first paper to test the relationships between job satisfaction and turnover intention, and workload and turnover intention in the context of IT projects within the Madinah Government of Saudi Arabia. Secondly, according to the results, there is a negative moderate relationship between job satisfaction and IT employees' turnover intention $(r=-0.532, \mathrm{p}<0.01)$. Thus, lower job satisfaction is related to a higher turnover of IT employees. Generally, this result supports previous studies of the job satisfactionturnover relationship. Also, this study supports that there is a positive small relationship between workload and IT employees' turnover intention $(\mathrm{r}=0.318, \mathrm{p}<0.01)$. This means that a higher workload is related to a higher turnover of IT employees. This is in line with studies discussed previously in the literature review. According to Tables 4 and 5 , this paper presents the relationships among job satisfaction, workload, and turnover intention in IT projects within the Madinah Government, as shown in the relationship model (Figure 2).

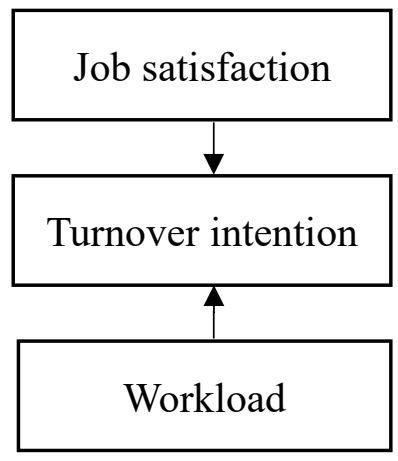

Figure 2: Relationship Model 
The relationship model explains the associations between the two independent variables and one dependent variable. This study argues that an IT employee with high job satisfaction is more likely to stay with an employer for a long period of time. Furthermore, an IT employee with a heavy workload is more likely to leave an employer and seek a new job.

\section{Conclusions}

Although the influence of turnover intention can be positive or negative on firms and employees, turnover continues to be one of the most significant managerial challenges in the field of IT projects. This study is the first work to explore the relationships between the three variables: job satisfaction, workload and turnover intention in IT projects within the Madinah Government of Saudi Arabia. This paper studied the level of job satisfaction, workload, and turnover intention among IT project employees. Consistent with the extant literature, the study findings provided empirical evidence that job satisfaction has a direct significant influence on IT turnover intention. Also, as in other previous studies, workload has been associated with IT turnover intention.

One key limitation of this study is that the sample was small and data were collected only from IT employees within the Madinah Government. Thus, findings cannot be generalized beyond this area in Saudi Arabia. Despite its research limitations, the study contributed significantly to the literature of job satisfaction, workload, and turnover intention. More research is recommended to determine if the results of this study can be generalized to other areas of Saudi Arabia. Also, future research should test other variables that may influence turnover intention.

\section{References}

Alexander, B. (2015). An empirical investigation of the relationship between workload and performance, Management Decision, Vol. 53 Iss 10 .

Armstrong, M. (2006). Human Resources Management. 9th Edition. London: Free Press

Baroudi, J. J. (1985). The impact of role variables on is personnelwork attitudes and intentions. Management Information System Quarterly, 9(4), 341-356.

Ben-Baker,K.A., Al-Shammari,I.S., Jefri,O.A., \& Prasad, J.N.(1994). Organizational commitment, satisfaction and turnover in Saudi organizations: A Predictive study. The Journal of SocioEconomics, 23(4):449-456.

Bernstein, D. A., \& Nash, P. W. (2008). Essentials of psychology (4th ed.). Boston: Cengage Learning.

Bliss, W. G. (2004). Cost of Employee Turnover. Retrieved from http://www.isquare.com/turnover.cfm (accessed on July21, 2018).

Bowling, N. A., \&Kirkendall, C. (2012). Workload: A review of potential causes, consequences, and interventions. In J. Houdmont, S. Leka, \& R. Sinclair (Eds.), Contemporary occupational health psychology: Global perspectives on research and practice (Vol. 2, pp. 221-238). Chichester: WileyBlackwell.

Brief, A.P.(1998). Attitudes in and Around Organizations vol. 9. Sage.

DeVellis, R. (2003).Scale Development: Theory and Applications. Sage Publications, Thousand Oaks, CA.

Dohm, A., \& Shniper, L. (2007). Occupational employment projections to 2016. Monthly Labor Review, 2007, $86-125$.

Essex, D. (2000). Employee turnover: The costs are staggering. ITWorld.com. Retrieved from https://www.itworld.com/article/2783476/careers/employee-turnover--the-costs-are-staggering.html (accessed on June2, 2018).

Fox, M.L., Dwyer, D.J., Ganster, D.C. (1993). Effects of stressful job demands and control on physiological and attitudinal outcomes in a hospital setting. Academy of Management Journal, 36(2), 289-218.

Gaillard, A.W.K. (2001). Stress, workload, and fatigue as three biobehavioral states: a general overview. In P.A. Hancock \& P.A. Desmond (Eds.), Stress, workload, and fatigue (pp. 623-639). NJ: Lawrence Erlbaum Associates.

Glaser, D.N., B.C. Tatum, D.M. Nebeker, R.C. Sorenson and J.R. Aiello, (1999). Workload and social support: Effects on performance and stress. Human Performance, 12: 155-176.

Gopher, D., \&Donchin, E. (1986). Workload - An examination of the concept. In K.R. Boff, L. Kaufman, \& J.P. Thomas (Eds.), Handbook of perception and human performance. NY: Wiley \& Sons.

Government of Saudi Arabia. (2016). Saudi Arabia's Vision for 2030. Available online: http://vision2030.gov.sa/en (accessed on 07July 2018). 
Griffeth, R. W., \&Hom, P. W. (1995). The employee turnover process. Research in

Hackman, J. R., \& Oldham, G. R. (1980). Work redesign. Reading: Addison-Wesley.

Hammerberg, J. H. (2002). Reasons given for employee turnover in a full priced department store. University of Wisconsin-Stout.

Herzberg, F., Mausne, B., \& Snyderman, B. (1959). The Motivation to Work. Jhon Wiley.

Hester, J. (2013). The high cost of employee turnover and how to avoid it. Nonprofit World, 31(3), 20-21. Retrieved fromhttp://www.snpo.org/publications/nonprofitworld.php

Holtom, B. C., \& Burch, T. C. (2016). A model of turnover-based disruption in customer services. Human Resource Management Review, 26(1), 25-36.

Igbaria, M., \& Siegel, S. R. (1992). The reasons for turnover of information systems personnel. Information \& Management, 23 (6), 321-330.

IT Report,(2015). Kingdom of Saudi Arabia. The Communications and Information Technology Commission (CITC).

ITEC, (1998). "Information Technology Policy 2510 - Oversight of Information Technology Projects." from http://www.da.ks.gov/kito/itec/policies/itecitpolicy2510.htm.

J.P. Meyer and N.J. Allen. (1997). Commitment in the workplace: Theory, research and application. Thousand Oaks, CA: Sage Publications.

Jiang, J. J., \& Klein, G. (2002). A discrepancy model of information system personnel turnover. Journal of Management Information Systems, 19(2), 249-272.

Jones, M. (2006). Which is a better predictor of job performance: Job satisfaction or life satisfaction? Journal of Behavioral and Applied Management. Vol. 8

Judge, T. A., \& Bono, J. E. (2001). Relationship of core self-evaluations traits—self-esteem, generalized selfefficacy, locus of control, and emotional stability — with job satisfaction and job performance: A metaanalysis. Journal of Applied Psychology, 86, 80-92.

Judge, T. A., \& Watanabe, S. (1994). Individual differences in the nature of the relationship between job and life satisfaction. Journal of Occupational and Organizational Psychology, 67, 101-107.

Judge, T.A. and Larsen, R.J. (2001). Dispositional affect and job satisfaction: A review and theoretical extension. Organizational Behavior and Human Decision Processes. Sep 2001. Vol. 86, Is. 1; pp. 67-98.

Kamal, M. (2005). Information Technology Workforce--Planning for the Future, Journal of American Academy of Business, Vol. 7, 2, pp. 23-26.

Kazi, G. M., \& Zadeh, Z. F. (2011). The contribution of individual variables: job satisfaction and job turnover. Interdisciplinary Journal of Contemporary Research in Business, 3(5), 985-992.

Khan, S. A. (2014). The factors affecting employee turnover in an organization: The case of Overseas Pakistanis foundation. African Journal of Business Management, 8 (1), 25.

Kim, S. (2005). Factors affecting state government information technology employee turnover intentions. American Review of Public Administration. Vol. 35, No. 2, pp. 137-156.

Kim, S., \& Wright, B. E. (2007). IT employee work exhaustion: Toward an integrated model of antecedents and consequences. Review of Public Personnel Administration, 27(2), 147-170.

Laschinger, H.K.S., Finegan, J., Shamian, J., Almost, J. (2001). Testing Karasek's demands control model in restructured healthcare settings: Effects of job strain on staff nurses' quality of work life. Journal of Nursing Administration, 31(5), 233-243.

Lo, J. (2013). The information technology workforce: A review and assessment of voluntary turnover research. Information Systems Frontiers, 17(2), 387-411.doi:10.1007/s1076-013-9408-y

Locke, E. A. (1969). What is job satisfaction?. Organizational behavior and human performance, 4(4), 309-336.

Loher, B. T., Noe, R. A., Moeller, N. L., \& Fitzgerald, M. P. (1985). A meta-analysis of the relation of job characteristics to job satisfaction. Journal of applied psychology, 70(2), 280.

Martin, J., \& Schmidt, C. (2010). How to keep your top talent. Harvard Business Review, 88(5), 54-61. Retrieved from http://hbr.org.

Matthews, G., Davies, D.R., Westerman, S.J., \& Stammers, R.B. (2000). Human performance: Cognition, stress and individual differences. Hove, East Sussex: Psychology Press.

Mayer, R. E. (1989). Models for Understanding. Review of Educational Research, 59(1): 43-64.

Mello, J. A (2014).Strategic Human Resource Management, 3rd Ed, OH: South-western Cengage Learning.

Moore, J. E. (2000). One road to turnover: An examination of work exhaustion in technology professionals. MIS Quarterly, 24(1), 141-168. 
Nelson, R. R., \& Todd, P.A. (2004). Peopleware: The hiring and retention of IT personnel. Strategies for managing IS/IT personnel (pp. 1-17). Hershey: Idea Group.

Ortqvist, D., \&Wincent, J. (2006). Prominent consequences of role stress: A meta-analytic review. International Journal of Stress Management, 13, 399-422. doi:10.1037/1072-5245.13.4.399

Perez, M., DiDona, T. M., \& Suarez, M. (2013). Socialization of Recently Hired Hispanic Employees. The 2013 WEI International Academic Conference Proceedings.personnel and human resources management, 13(3), 245-293.

Reeves, S. (2005). Seven Deadly Interview Flubs. Retrieved from https://www.forbes.com/2005/10/05/employment-careers-interviewscx_sr_1006bizbasics.html\#7d9031921ed1(accessed on May14, 2018).

Rumsey, D. J. (2011). Statistics for dummies (2nd Ed.). Indianapolis, Indiana: Wiley Publishing, Inc.

Sanjeevkumar, V. (2012). A study on employee's intention to stay in public companies, Kedah, Malaysia. International Journal Business Economics and Management Research, 2(4), 91-101.

Shaw, J. \&Weekley, J., (1985). The effects of objective work-load variations of psychological strain and post work-load performance. Journal of Management, pp. 87-99.

Shoemaker, M. E. (1999). Leadership Practices in Sales Managers Associated with the Self-Efficacy, Role Clarity, and Job Satisfaction of Individual Industrial Salespeople. Journal of Personal Selling and Sales Management, 19, 4 (Fall), 1-19

Spector, P. (1997). Job Satisfaction: Application, Assessment, Causes and Consequences. California: Sage.

Standish Group, (1994). Chaos Report.Boston, MA.

Tett RP, Meyer JP (1993). Job Satisfaction, Organizational Commitment, Turnover Intention, and Turnover: Path Analyses Based on Meta-analytic Findings, Pers. Psychol. 46:259-293.

Thompson, T. L. (2008). The Relationship Between Job Satisfaction and Project Success: A Quantitative Study of Project Managers in Houston, Texas. Unpublished doctoral dissertation, Capella University.

Weiner, S. P. (2000). Worldwide technical recruiting in IBM: Research and action. In P. D. Bachiochi (Chair), Attracting and keeping top talent in the high-tech industry. Practitioner Forum at the Fifteenth Annual Conference of the Society for Industrial and Organizational Psychology, New Orleans, LA.

Woods, R. H. (1995). Managing Hospitality Human Resources. Educational Institute of the American Hotel and Motel Association. East Lansing, MI. 